\title{
The Significance of Encapsulation of Visual Perception for Philosophy of Mind and Aesthetic Analysis
}

\author{
Vladimir J Konečni*
}

Department of Psychology, University of California, San Diego, California 92093-0109, USA

\begin{abstract}
This Opinion Article highlights three sets of important implications of the very recent work by C. Firestone and B. Scholl on the encapsulation of visual perception: (a) methodological implications, especially with regard to experimental areas of cognitive science, such as cognitive social psychology; (b) implications of interest to philosophers of mind, some of whose more extravagant recent claims have been based on the assumption of "topdown" cognitive effects on perception; and (c) implications that challenge some recent work in philosophical and psychological aesthetics regarding art expertise, as well as defend the logic of A. Danto's theorizing from attacks that are based on the assumption of "top-down" cognitive effects.
\end{abstract}

Keywords: Perception; "Top-down" effects; Encapsulation of perception; "Top-down” cognitive effects on perception; Philosophy of mind; Philosophical aesthetics; Psychological aesthetics

The relationship between seeing and thinking is a matter second to none in importance in cognitive science. The pendulum has swung a number of times in the past sixty-five years between the position that perception is fully encapsulated and one that insists on its penetration by higher cognitive processes ("top-down" effects). In fact, if one were to take a longer and broader historical view and include the visual arts, literature, and humanities, the number of such swings would be considerably multiplied. However, Chaz Firestone and Brian Scholl (in press, [1]) perhaps err when they label the cognitivepenetrability avalanche of the past 25 years "revolutionary": Given the currently prevalent and fashionable position in cognitive science (if not vision science), it is, in fact, their own detailed and careful analysis supporting the notion of impenetrability of perception by cognition that is revolutionary, in the best sense, as well as defensible and immensely important.

The work of Firestone and Scholl (in press, [1]), together with their preceding articles [2,3], is important for at least three reasons. The first is methodological, with regard to experimental areas of cognitive science, especially cognitive social psychology, in which there is virtually an established tradition of allegedly counterintuitive, or "cute," findings that often turn out to be unreplicable or questionable in terms of the research "pitfalls" that have now been identified and laid bare by Firestone and Scholl. Their detailed description of these pitfalls is important, even though some of them are by no means "news." In fact, it would have been desirable if Firestone and Scholl (in press, [1]), in discussing, for example, the issue of task and response bias, also addressed kin methodological matters and gave more detailed credit than they did [4] to social psychologists' own incisive and multifaceted critiques of methodological problems and abuses in their field, with special reference to the classical studies [5-8].

The second reason for which the cumulative work by Firestone and Scholl is important is to be found in its potential to introduce discipline into some highly speculative, yet influential, conjectures about the nature of perception in the philosophy of mind [9-11]. In fact, the reaction to the article by Firestone and Scholl by philosophers of mind and of science, some of whom are known to have made a heavy intellectual investment in the penetrability-of-perception view, may influence the reception by the broader scientific community in experimental psychology, cognitive science, and neuroscience to the strong impenetrability (encapsulation of perception) view that is advocated by these two psychologists on the basis of the diverse sources of evidence that they have astutely and successfully summoned.

The third major explanation of the significance of this renewed support for the notion of impenetrability of perception lies in the challenges that are unambiguously raised for several influential recent analyses in both the psychology and philosophy of art. The most relevant articles are by Stokes [12], Nanay [13], and Bullot and Reber [14]. Stokes's [12] work is a major statement that attempts to link art expertise to cognitively penetrated perception. The attempt is in two parts. The first is highly speculative and relies on phenomenological and clinical (associative agnosia) accounts. But the second part, more relevant in the present context, invokes experiments on the "memory color effect" by Witzel et al. [15] and it is the validity of these findings that are clearly open to a serious challenge on the basis of at least three research pitfalls (those regarding judgment, "task demand," and recognition) that are described by Firestone and Scholl (in press, [1]).

As for Nanay [13], he disputes the truthfulness of the conclusion that Arthur Danto - arguably the most influential American philosophical aesthetician of the second half of the 20th century - reached by means of his famous (or notorious) "gallery of indiscernibles." Nanay does this by claiming $(2015$, p. 1$)$ that Danto's inference was based on the false premise that "perceptual experiences are not cognitively penetrable." In contrast, Nanay [13] believes that they are penetrable and calls upon precisely those experiments [16-18] that are highly suspect with regard to the research pitfalls described in detail by Firestone and Scholl (in press, [1]).

*Corresponding author: Vladimir J. Konečni, Department of Psychology, University of California, San Diego, California 92093-0109, USA, E-mail: vkonecni@ucsd.edu

Received: October 14, 2015; Accepted: October 17, 2015; Published: October 21, 2015

Citation: Konečni VJ (2015) The Significance of Encapsulation of Visual Perception for Philosophy of Mind and Aesthetic Analysis. Clin Exp Psychol 1: 102. doi:10.4172/ cep. 1000102

Copyright: (c) 2015 Konečni VJ. This is an open-access article distributed under the terms of the Creative Commons Attribution License, which permits unrestricted use, distribution, and reproduction in any medium, provided the original author and source are credited. 
Citation: Konečni VJ (2015) The Significance of Encapsulation of Visual Perception for Philosophy of Mind and Aesthetic Analysis. Clin Exp Psychol 1: 102. doi:10.4172/2471-2701.1000102

Page 2 of 2

Finally, Bullot and Reber [14] claim that paintings "can elicit a variety of automatic emotional responses" (italics added), such as anger, fear, and sadness (their Figure 2 and section 3.1.2., p. 128). This was challenged by Konečni $[19$, p. 307] on a variety of theoretical and empirical grounds. Significantly, the analysis by Firestone and Scholl (in press, [1]). not only supports the earlier critique by Konečni [19], but helps extend it to other aspects of the general position held by Bulllot and Reber [14] - one that excessively relies on Walton's [20] historicalcontextualist theory of art appreciation (also adopted, incidentally, by Stokes, 2014).

Since Jerry Fodor's influential book on the "modularity of mind" [21], and his debate with Churchland [22,23] regarding this issue, as well as his later writing on Danto [24], the notion of impenetrability of perception was first on an apparent upswing, and then on the downswing (except in basic vision science). Articles by Firestone and Scholl will presumably reverse the downward trend. However, the notion that thought is able to "penetrate" seeing - to a certain extent, under some circumstances - nevertheless, in the opinion of this author, remains viable, especially with regard to several important issues in the area of attention. Firestone and Scholl (in press, [1]) allude to this in a part of their article in which their account is the most tentative and perhaps the least persuasive. But such effects, even if detectable, are too subtle to refute the major aspects of the modularity and impenetrability positions.

\section{References}

1. Firestone $C$ \& Scholl B J (in press). Cognition does not affect perception: Evaluating the evidence for 'top-down' effects. Behavioral and Brain Sciences.

2. Firestone C \& Scholl B J (2015a). Can you experience top-down effects on perception? The case of race categories and perceived lightness. Psychonomic Bulletin \& Review, 22: 694-700.

3. Firestone C \& Scholl,B J (2015b). Enhanced visual awareness for morality and pajamas? Perception vs. memory in top-down effects. Cognition, 136: 409-416

4. Rosenthal R \& Rubin D B (1978). Interpersonal expectancy effects: The first 345 studies. Behavioral and Brain Sciences, 1: 377-386.

5. Campbell D T \& Stanley J C (1963). Experimental and quasi-experimental designs for research. Boston, MA: Houghton Mifflin Company.

6. Orne M (1962). On the social psychology of the psychological experiment: With particular reference to demand characteristics and their implications. American
Psychologist, 17: 776-783.

7. Rosenthal R \& Jacobson L (1968). Pygmalion in the classroom. New York, NY: Holt, Rinehart \& Winston.

8. Rosenthal R \& Rosnow R L (Eds.). ( 1969). Artifact in behavioral research. New York, NY: Academic Press.

9. Clark A (2013). Whatever next? Predictive brains, situated agents, and the future of cognitive science. Behavioral and Brain Sciences, 36: 181-204.

10. Clark A, \& Chalmers D (1998). The extended mind. Analysis, 58: 7-19.

11. Lupyan G \& Clark A (2015). Words and the world: Predictive coding and the language-perception-cognition interface. Current Directions in Psychological Science, 24: 279-284.

12. Stokes D (2014). Cognitive penetration and the perception of art. Dialectica 68:1-34.

13. Nanay B (2015). Cognitive penetration and the gallery of indiscernibles. Frontiers in Psychology, 5: 1527.

14. Bullot N J \& Reber R (2013). The artful mind meets art history: Toward a psycho-historical framework for the science of art appreciation. Behavioral and Brain Sciences, 36: 123-180.

15. Witzel C, Valkova H, Hansen T \& Gegenfurtner K R (2011). Object knowledge modulates colour appearance. i-Perception, 2: 13-49.

16. Goldstone R L (1995). Effects of categorization on color perception. Psychological Science, 6: 298-304.

17. Hansen T, Olkkonen M, Walter S \& Gegenfurtner K R (2006). Memory modulates color appearance. Nature Neuroscience, 9: 1367-1368.

18. Lupyan G, Thompson-Schill S L \& Swingley D (2010). Conceptual penetration of visual processing. Psychological Science, 21: 682-691.

19. Konečni V J (2015). Emotion in painting and art installations. American Journal of Psychology, 128: 305-322.

20. Walton K (1970). Categories of art. Philosophical Review, 79: 334-367.

21. Fodor J A (1983). The modularity of mind: An essay in faculty psychology. Cambridge, MA: MIT Press.

22. Churchland P M (1988). Perceptual plasticity and theoretical neutrality: A reply to Jerry Fodor. Philosophy of Science, 55: 167-187.

23. Fodor J A (1988). A reply to Churchland's "Perceptual plasticity and theoretical neutrality". Philosophy of Science, 55: 188-198.

24. Fodor J A (1993). Déjà vu all over again: How Danto's aesthetic recapitulates the philosophy of mind. In M. Rollins (Ed.), Arthur Danto and his critics (pp. 41 54). Oxford, England: Blackwell. 